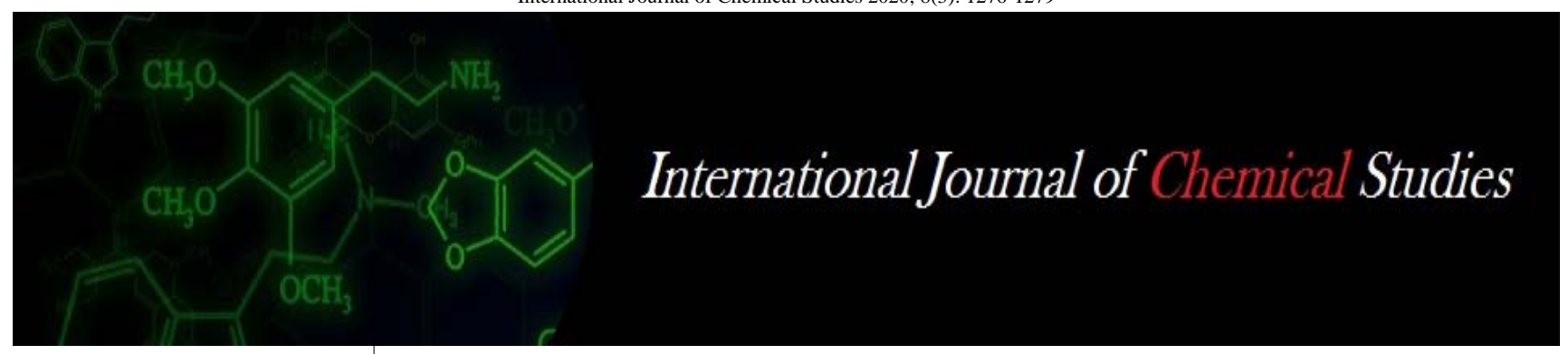

P-ISSN: 2349-8528 E-ISSN: 2321-4902 www.chemijournal.com IJCS 2020; 8(3): 1276-1279 (C) 2020 IJCS

Received: 24-03-2020 Accepted: 26-04-2020

\section{R Pati}

Department of Soil Science and Agril. Chemistry, Palli Siksha Bhavana, Institute of Agriculture, Visva Bharati, Santiniketan, Birbhum, West Bengal, India

\section{AK Chatterjee}

Department of Soil Science and Agril. Chemistry, Palli Siksha Bhavana, Institute of Agriculture, Visva Bharati, Santiniketan, Birbhum, West Bengal, India

\section{Mukhopadhyay} Department of Soil Science and Agricultural Chemistry, Uttar Banga Krishi Viswavidyalaya, Pundibari, Cooch Behar, West Bengal, India

\section{Corresponding Author:} R Pati

Department of Soil Science and Agril. Chemistry, Palli Siksha Bhavana, Institute of Agriculture, Visva Bharati, Santiniketan, Birbhum, West Bengal, India

\section{Effect of lime, organic matter and boron on the use efficiency of phosphorus in lentil (Lens culinaris L.)}

\author{
R Pati, AK Chatterjee and D Mukhopadhyay
}

DOI: https://doi.org/10.22271/chemi.2020.v8.i3q.9377

\section{Abstract}

An experiment with lentil (Lens culinaries L.) was conducted at the terai situation of West Bengal (India) under different combination of phosphorus, boron and farm yard manure (FYM). The soil was acidic (pH-5.35) in reaction with sandy -loam in texture and hence, liming material was applied to find out the use efficiency of the phosphorus (P) in determining the yield potential of the crop (lentil). The maximum grain yield of lentil was 13.93 qha $^{-1}$ at the lime- treated soil compared to the untreated control $\left(6.63 \mathrm{qha}^{-1}\right)$. The seed yield was increased from 9.64 to $13.85 \mathrm{qha}^{-1}$ with the increasing level of P. The effect of P was relatively lower in a soil not treated with lime. The Physiological Harvest Index (PHI) was higher (56.67) when P @ $60 \mathrm{kgha}^{-1}$ was applied irrespective of any treatment combinations and was minimum (54.95) at the lower rate of $\mathrm{P}\left(30 \mathrm{kgha}^{-1}\right)$ application. The maximum Agronomic efficiency (AE) was 18.3 and that of Physiological Efficiency (PE) was 85.16 at the lower rate of $\mathrm{P}\left(30 \mathrm{kgha}^{-1}\right)$ application. Hence, application of lime in soil with organic matter and B can improve the use efficiency of $\mathrm{P}$ for lentil in an acidic soil of a region.

Keywords: Phosphorus, lentil, boron, farm yard manure

\section{Introduction}

The intensification of agriculture through crop diversification in a sequence has become an essential need of the day, as for the restricted scope for horizontal expansion of area of land under plough. Hence, the most vital natural resource, i.e. soil, requires proper attention to maintain its resilience for sustained crop production. The soils under Terai situation, are generally sandy loam in texture, acidic in reaction, high in raw humus content, low in water retention capacity, medium to high in total nitrogen and low to medium in potassium content. The deficiency of available zinc and boron in most of the soils of North Bengal are also observed. The inadequacy of plant available phosphorus (P) in acid soils (Graham, 1955) ${ }^{[5]}$ was reported even though the total amount of phosphorus apparently exceed the crop or pasture requirement. The applied phosphorus are very often fixed as $\mathrm{Al}$ and $\mathrm{Fe}$-phosphate in the region and thus reducing the efficiency of P-fertilizer. The area expansion of the pulse crops is a challenge by improving the production technology with the minimum exploitation of the natural resources. Besides, knowledge of genes controlling important agronomic and quality traits is critical (Wani et al., 2017) ${ }^{[22]}$ for plant breeders to develop proper strategies for efficient breeding programs. Keeping this in perspectives, the use efficiency of $\mathrm{P}$ in lentil under the low $\mathrm{pH}$ condition in soil was considered with a view to maximize the yield of the crop. An experiment on Lentil in Terai situation of West Bengal (Singha Roy et al., 1992) ${ }^{[20]}$, showed that phosphate fertilizer and micronutrients (B and $\mathrm{Zn}$ ) application in soil significantly increased the dry matter accumulation and filled pods per plant. The fixation of phosphorus by the iron and aluminium oxides and hydroxides has become a problem in supplying the phosphorus to the plants in demand and hence, much of the applied fertilizer - $\mathrm{P}$ is locked up in the soil rendering unavailable to plants (Marschner, 1995) ${ }^{[13]}$., although, the recovery of the phosphorus by the plants after application is often 10-20\% (Sharpley,1985; McLaughlin et al., 1987) ${ }^{[16,14]}$. Maqsood et al. (1994) ${ }^{[12]}$ have reported the effect of seed inoculation with rhizobium and $\mathrm{P}$ on nodulation, growth and yield components of lentil and observed that the combined application of rhizobium and $\mathrm{P}$, influenced favourably on the number of pods per 
plant, number of seeds per pod and 1000 seed weight of the crop. Singh et al. (2004) ${ }^{[19]}$ while conducting the field experiment with lentil observed that, the residual effects of organic sources influenced significantly on the yield, nutrient uptake and net return of lentil over the untreated control. The cultivable areas under pulse crops has been narrowing in West Bengal (India) compare to other regions of the state, owing to the lack of adoption of improved agro techniques including fertilizer application with proper doses (Mandal et al.,2009) [11]. Based on the above perspectives, the present study was undertaken with a view to improve the use efficiency of phosphorus under lime, organic matter and boron application in soil.

\section{Materials and methods}

The field experiments were carried out with lentil, [Cv. Asha (B -77)] at the Instructional farm, Uttar Banga Krishi Viswavidyalaya, Pundibari, Cooch Behar of West Bengal during the Rabi season. Composite soil samples from the plots were collected and analyzed before the start of the experiment. The design adopted was split plot in which there were six main plot treatments and four sub-plot treatments. Hence, twenty four treatment combinations (Lime, Phosphorus and Farm Yard Manure) were there and each treatment combination was replicated thrice giving a total of 72 unit plots, each measuring $3.5 \mathrm{~m} \times 3 \mathrm{~m}$. The $\mathrm{N}: \mathrm{P}: \mathrm{K}$ as a recommended dose $\left(\mathrm{kgha}^{-1}\right)$ of 30:60:60 was applied to the soil. The lime as $\mathrm{CaCO}_{3}$, organic matter $(\mathrm{F})$ as decomposed farm yard manure and $\mathrm{B}$ as Borax were applied as the source of nutrients to the crop. The $\mathrm{L}_{1}=\operatorname{Lime}\left(\mathrm{CaCO}_{3}\right)$ as per lime requirement, $\mathrm{Lo}=$ No lime application, $\mathrm{Po}=$ No phosphorus application, $\mathrm{P}_{1 / 2}=$ Half of the recommended dose $\mathrm{P}_{1}=$ Full of the recommended dose, Fo $=$ No Farm yard Manure, $F_{1}=$ FYM @ 10 t/ha, Bo = No Borax application, $B_{1}=$ Full of the recommended dose (10 $\mathrm{kgha}^{-1}$ as Borax) were applied. The details of the treatment combinations are: $\mathrm{T}_{1}-\mathrm{L}_{1} \mathrm{~F}_{1} \mathrm{P}_{0} \mathrm{~B}_{0} ; \mathrm{T}_{2}-$ $\mathrm{L}_{1} \mathrm{~F}_{1} \mathrm{P}_{0} \mathrm{~B}_{1} ; \mathrm{T}_{3}-\mathrm{L}_{1} \mathrm{~F}_{1} \mathrm{P}_{1 / 2} \mathrm{~B}_{0} ; \mathrm{T}_{4}-\mathrm{L}_{1} \mathrm{~F}_{1} \mathrm{P}_{1 / 2} \mathrm{~B}_{1} ; \mathrm{T}_{5}-\mathrm{L}_{1} \mathrm{~F}_{1} \mathrm{P}_{1} \mathrm{~B}_{0} ; \mathrm{T}_{6}-$ $\mathrm{L}_{1} \mathrm{~F}_{1} \mathrm{P}_{1} \mathrm{~B}_{1} ; \mathrm{T}_{7-} \mathrm{L}_{1} \mathrm{~F}_{0} \mathrm{P}_{0} \mathrm{~B}_{0} ; \mathrm{T}_{8}-\mathrm{L}_{1} \mathrm{~F}_{0} \mathrm{P}_{0} \mathrm{~B}_{1} ; \mathrm{T}_{9}-\mathrm{L}_{1} \mathrm{~F}_{0} \mathrm{P}_{1 / 2} \mathrm{~B}_{0} ; \mathrm{T}_{10}-$ $\mathrm{L}_{1} \mathrm{~F}_{0} \mathrm{P}_{1 / 2} \mathrm{~B}_{1} ; \mathrm{T}_{11}-\mathrm{L}_{1} \mathrm{~F}_{0} \mathrm{P}_{1} \mathrm{~B}_{0} ; \mathrm{T}_{12}-\mathrm{L}_{1} \mathrm{~F}_{0} \mathrm{P}_{1} \mathrm{~B}_{1} ; \mathrm{T}_{13}-\mathrm{L}_{0} \mathrm{~F}_{1} \mathrm{P}_{0} \mathrm{~B}_{0} ; \mathrm{T}_{14}$ $\mathrm{L}_{0} \mathrm{~F}_{1} \mathrm{P}_{0} \mathrm{~B}_{1} ; \mathrm{T}_{15}-\mathrm{L}_{0} \mathrm{~F}_{1} \mathrm{P}_{1 / 2} \mathrm{~B}_{0} ; \mathrm{T}_{16}-\mathrm{L}_{0} \mathrm{~F}_{1} \mathrm{P}_{1 / 2} \mathrm{~B}_{0} ; \mathrm{T}_{17}-\mathrm{L}_{0} \mathrm{~F}_{1} \mathrm{P}_{1} \mathrm{~B}_{0} ; \mathrm{T}_{18}-$ $\mathrm{L}_{0} \mathrm{~F}_{1} \mathrm{P}_{1} \mathrm{~B}_{1} ; \mathrm{T}_{19}-\mathrm{L}_{0} \mathrm{~F}_{0} \mathrm{P}_{0} \mathrm{~B}_{0} ; \mathrm{T}_{20}-\mathrm{L}_{0} \mathrm{~F}_{0} \mathrm{P}_{0} \mathrm{~B}_{1} ; \mathrm{T}_{21}-\mathrm{L}_{0} \mathrm{~F}_{0} \mathrm{P}_{1 / 2} \mathrm{~B}_{0} ; \mathrm{T}_{22}-$ $\mathrm{L}_{0} \mathrm{~F}_{0} \mathrm{P}_{1 / 2} \mathrm{~B}_{1} ; \mathrm{T}_{23}-\mathrm{L}_{0} \mathrm{~F}_{0} \mathrm{P}_{1} \mathrm{~B}_{0} ; \mathrm{T}_{24}-\mathrm{L}_{0} \mathrm{~F}_{0} \mathrm{P}_{1} \mathrm{~B}_{1}$. The important soil properties ( $\mathrm{pH}, \mathrm{EC}$, oxidisable organic carbon, available $\mathrm{N}, \mathrm{P}$ and K) were determined by the standard method (Jackson,1973) ${ }^{[7]}$. The available- $\mathrm{P}$ content of the experimental soils was determined by the method of Bray and Kurtz (1945) ${ }^{[3]}$. The plant samples were collected from each plot at harvest, cleaned and oven dried at $60^{\circ} \mathrm{C}$ and chopped for grinding. The uptake of $\mathrm{P}$ by grain was measured (Jackson, 1973) ${ }^{[7]}$. The grain yield was taken per plot. The statistical analysis was done by the method as described by Gomez and Gomez (1984) ${ }^{[4]}$. The AE [i.e. seed yield of fertilized plot(kg)-seed yield of control(kg)/quantity of fertilizer applied $(\mathrm{kg})$ and PE [total dry matter yield of fertilized plot (kg)- total dry matter yield of control plot (kg)/nutrient uptake by fertilized plot(kg)-nutrient uptake by control plot (kg) were calculated (Baligar et al.,2001) ${ }^{[1]}$.

\section{Results and discussion}

From the soil analysis, it was observed that the soil was acidic in reaction ( $\mathrm{pH}-5.35)$ having the electrical conductivity as $0.08 \mathrm{dSm}^{-1}$, the oxidisable organic carbon as $1.14 \mathrm{gkg}^{-1}$ and the texture as sandy- loam. The available $\mathrm{N}, \mathrm{P}, \mathrm{K}$ in soil were recorded as $117.6,17.2$ and $120.9 \mathrm{kgha}^{-1}$ respectively. The well decomposed farm yard manure (FYM) having the $\mathrm{N}$
(0.72\%), P (0.30\%) and K (0.70\%) was applied at different doses in soils to study the effect (if any) on lentil.

The effect of treatments on yield components and yield of lentil during the first and second year were recorded to compute the average yield [Figure 1(a) and 1(b)] of the crop. The significant yield differences were observed between the treatment combinations. The maximum average seed yield (13.93 qha $^{-1}$ ) of lentil [Figure 1(a)] was obtained in $T_{6}$ where, lime was applied. The minimum average seed yield was recorded as 6.63 qha $^{-1}$ in soil being untreated control $\left(T_{19}\right)$. The soil without lime [Figure 1(b)] rendered 13.59 qha $^{-1}$ seed yield where the FYM and $\mathrm{P}$ were applied in combinations. The effect of P and FYM towards the increase in yield of lentil was reported by Kumar et al. (2010) ${ }^{[9]}$. The effect of lime and $\mathrm{P}$ on seed yield of lentil showed that minimum yield $9.64 \mathrm{qha}^{-1}$ was obtained in the treatment $\mathrm{T}_{1}\left(\mathrm{~L}_{1} \mathrm{~F}_{1} \mathrm{P}_{0} \mathrm{~B}_{0}\right)$ compared to 12.78 qha $^{-1}$ in $\mathrm{T}_{3}\left(\mathrm{~L}_{1} \mathrm{~F}_{1} \mathrm{P}_{1} /{ }_{2} \mathrm{~B}_{0}\right)$ and 13.85 qha $^{-1}$ in $\mathrm{T}_{5}\left(\mathrm{~L}_{1} \mathrm{~F}_{1} \mathrm{P}_{1} \mathrm{~B}_{0}\right)$ respectively. With the increase of the level of $\mathrm{P}$, the seed yield $\left(\mathrm{qha}^{-1}\right)$ also increased in $\mathrm{T}_{5}$ (13.85) $>T_{3}(12.78)>T_{1}(9.64)$. The presence of lime in combination with the graded doses of $\mathrm{P}$ gave relatively higher yield compared to the soil not treated with lime. The effect on combined application of lime, FYM, P and B towards the maximum (13.93 qha-1) yield of the crop was observed in $\mathrm{T}_{6}$ [Figure 1(a)]. It has been also observed that the combined application of lime, $\mathrm{P}$ and $\mathrm{B}$ had significant influence on changing the yield attributes and yield of the lentil. The increase in yield [Figure 1(a)] at the treatment $T_{10}$ $\left(\mathrm{L}_{1} \mathrm{~F}_{0} \mathrm{P}_{1 / 2} \mathrm{~B}_{1}\right)$ and $\mathrm{T}_{12}\left(\mathrm{~L}_{1} \mathrm{~F}_{0} \mathrm{P}_{1} \mathrm{~B}_{1}\right)$ over that of $\mathrm{T}_{8}\left(\mathrm{~L}_{1} \mathrm{~F}_{0} \mathrm{P}_{0} \mathrm{~B}_{1}\right)$ might be due to the positive interaction among the $\mathrm{B}$, lime and $\mathrm{P}$ influencing the yield of the crop, which was somewhat lower in the treatments $\mathrm{T}_{7}\left(\mathrm{~L}_{1} \mathrm{~F}_{0} \mathrm{P}_{0} \mathrm{~B}_{0}\right), \mathrm{T}_{9}\left(\mathrm{~L}_{1} \mathrm{~F}_{0} \mathrm{P}_{1 / 2} \mathrm{~B}_{0}\right)$ and $\mathrm{T}_{11}$ $\left(\mathrm{L}_{1} \mathrm{~F}_{0} \mathrm{P}_{1} \mathrm{~B}_{0}\right)$. The average yield ( $\left(\mathrm{qha}^{-1}\right)$ of lentil was lower in the treatments $T_{20}$ (7.47), $T_{22}(10.1)$ and $T_{24}$ (10.73) where lime was not applied in the soil [Figure 1(b)]. The effects of $\mathrm{P}$ on seed yield ( $\mathrm{qha}^{-1}$ ) of lentil [Figures 1(a) and 1(b)] showed that there was a significant yield differences, between the $\mathrm{P}$ treated and untreated control plots. The yield (10.39 $\mathrm{qha}^{-1}$ and $11.53 \mathrm{qha}^{-1}$ ) of lentil [Figure 1(a)] due to the application of $\mathrm{P}$ and lime ( $\mathrm{T}_{9}$ and $\mathrm{T}_{11}$ ) could change significantly the yield gap for lentil in respect to the untreated control $\left(T_{19}\right)$. This was in support of the observation reported by Hussain et al., (2002)

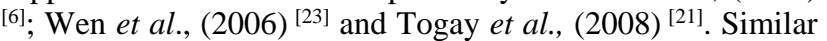
effect of $\mathrm{P}$ on summer green gram (Vigna radiata L.) was observed elsewhere by Rathour et al. (2015) ${ }^{[15]}$.

The seed yield $\left(\mathrm{qha}^{-1}\right)$ of lentil [Figure 1(a)] at the treatment $\mathrm{T}_{1}$ and $\mathrm{T}_{13}$ were 9.64 and 7.81 respectively where, FYM was applied in soil irrespective of the lime application. The average seed yield ( $\mathrm{qha}^{-1}$ ) was 7.81 , where, only FYM $\left(\mathrm{T}_{13}\right)$ was considered as the source of nutrients for lentil. Similar trend was observed by Singh et al. (2001) ${ }^{[18]}$ while conducting experiment with lentil elsewhere. The effects of B on seed yield (7.47 q/ha) of lentil [Figure 1(b)] showed that the yield was significantly increased in the treatment $\left(\mathrm{T}_{20}\right)$ where, B was applied as a sole source of nutrient over that of the untreated control $\left(\mathrm{T}_{19}\right)$. This was in support of the reports given by Johnson et al. (2005) ${ }^{[8]}$ and Mahler and Shafii (2007) ${ }^{[10]}$. It has been reported (Biswas,2015) ${ }^{[2]}$ that seed inoculation with (Rhizobium + PSB) along with $45 \mathrm{~kg}$ $\mathrm{P}_{2} \mathrm{O}_{5}$ /ha may be effectively recommended for improving crop growth, microbial population in respect of soil health, nodulation and seed yield of lentil. It was found that (Table1) the apparent fertilizer $\mathrm{P}$ - utilization (APU) was highest (23.92\%) with lower doses of $\mathrm{P}$ addition $\left(30 \mathrm{kgha}^{-1}\right)$. In presence of lime, the APU was relatively lower (5.81\%) than 
that of organic matter (16.16\%) and B (8.63\%). The Physiological harvest index (PHI) did not differ significantly on the phosphatic fertilizer applied. The PHI was maximum (60.14) at the P level of $60 \mathrm{kgha}^{-1}$ in presence of organic matter and minimum (54.95) at the P-level of $30 \mathrm{kgha}^{-1}$ in absence of lime, boron and organic matter. The agronomic efficiency (AE) and physiological efficiency (PE) were found relatively higher at lower rate of $\mathrm{P}$ application. The maximum $\mathrm{AE}$ (18.3) was at the $\mathrm{P}$ level of $30 \mathrm{kgha}^{-1}$ in presence of organic mater and that of maximum PE (85.16) was at the $\mathrm{P}$ level of $30 \mathrm{kgha}^{-1}$ found in absence of lime, B and organic matter. Hence, a general trend of improving the $\mathrm{AE}$ and $\mathrm{PE}$ at lower level of $\mathrm{P}$ application was observed in soil when applied with each of organic matter and $\mathrm{B}$. The AE of the crop improved when $\mathrm{P}$, at a lower rate was applied with organic matter or $\mathrm{B}$ in combination. The trend was in accordance with the observation given by Singh, et al. (2015) [17].

Table 1: Effect of phosphorus, lime, organic matter and boron on phosphorus use efficiency of lentil

\begin{tabular}{|c|c|c|c|c|c|c|}
\hline Treatments & $\begin{array}{c}\text { APU from } \\
\text { fertilizer } \\
\text { (\% recovery) }\end{array}$ & $\begin{array}{c}\text { APU from } \\
\text { native }\end{array}$ & $\begin{array}{c}\text { APU from } \\
\text { both }\end{array}$ & PHI & $\begin{array}{c}(\mathrm{AE}) \\
\text { (kg grain per kg } \mathrm{P} \\
\text { applied) }\end{array}$ & $\begin{array}{c}P E \\
\begin{array}{c}\text { (kg grain per kg of } P \\
\text { absorbed) }\end{array} \\
\end{array}$ \\
\hline \multicolumn{7}{|c|}{$\begin{array}{l}\text { In absence of Lime, B, and } \\
\text { organic mater }\end{array}$} \\
\hline $\begin{array}{c}\mathrm{P}_{2} \mathrm{O}_{5} \mathrm{~kg} \mathrm{ha}^{-1} \\
0 \mathrm{~kg} \\
30 \mathrm{~kg} \\
60 \mathrm{~kg} \\
\text { L.S.D }(\mathrm{P}=0.05) \\
\end{array}$ & $\begin{array}{c}---\overline{1} \\
13.07 \\
8.07 \\
0.041\end{array}$ & $\begin{array}{c}---- \\
30.2 \\
15.1 \\
0.262\end{array}$ & $\begin{array}{c}---- \\
43.27 \\
23.17 \\
0.031\end{array}$ & $\begin{array}{l}55.13 \\
54.95 \\
56.67 \\
0.020\end{array}$ & $\begin{array}{c}---- \\
11.13 \\
6.52 \\
0.035\end{array}$ & $\begin{array}{c}---- \\
85.16 \\
80.72 \\
0.061\end{array}$ \\
\hline \multicolumn{7}{|l|}{ In presence of lime } \\
\hline $\begin{array}{c}\mathrm{P}_{2} \mathrm{O}_{5} \mathrm{~kg} \mathrm{ha}^{-1} \\
0 \mathrm{~kg} \\
30 \mathrm{~kg} \\
60 \mathrm{~kg} \\
\text { L.S.D }(\mathrm{P}=0.05) \\
\end{array}$ & $\begin{array}{c}--- \\
6.01 \\
5.81 \\
0.031\end{array}$ & $\begin{array}{l}--- \\
39.59 \\
19.80 \\
0.029 \\
\end{array}$ & $\begin{array}{c}--- \\
45.60 \\
25.61 \\
0.041\end{array}$ & $\begin{array}{l}58.1657 .14 \\
59.28 \\
0.013\end{array}$ & $\begin{array}{c}--- \\
3.70 \\
3.75 \\
0.041\end{array}$ & $\begin{array}{c}---- \\
61.59 \\
64.53 \\
0.032\end{array}$ \\
\hline \multicolumn{7}{|c|}{ In presence of organic mater } \\
\hline $\begin{array}{c}\mathrm{P}_{2} \mathrm{O}_{5} \mathrm{~kg} \mathrm{ha}^{-1} \\
0 \mathrm{~kg} \\
30 \mathrm{~kg} \\
60 \mathrm{~kg} \\
\text { L.S.D }(\mathrm{P}=0.05) \\
\end{array}$ & $\begin{array}{c}--- \\
23.92 \\
16.16 \\
0.032\end{array}$ & $\begin{array}{c}---- \\
30.23 \\
15.11 \\
0.048 \\
\end{array}$ & $\begin{array}{c}--- \\
54.15 \\
31.27 \\
0.052\end{array}$ & $\begin{array}{l}55.17 \\
58.76 \\
60.14 \\
0.078\end{array}$ & $\begin{array}{c}---- \\
18.3 \\
11.62 \\
0.041\end{array}$ & $\begin{array}{c}-\overline{---} \\
76.48 \\
71.89 \\
0.042\end{array}$ \\
\hline \multicolumn{7}{|l|}{ In presence of $B$} \\
\hline $\begin{array}{c}\mathrm{P}_{2} \mathrm{O}_{5} \mathrm{~kg} \mathrm{ha}^{-1} \\
0 \mathrm{~kg} \\
30 \mathrm{~kg} \\
60 \mathrm{~kg} \\
\text { L.S.D }(\mathrm{P}=0.05)\end{array}$ & $\begin{array}{c}---- \\
13.91 \\
8.63 \\
0.047\end{array}$ & $\begin{array}{c}---- \\
30.22 \\
15.11 \\
0.047\end{array}$ & $\begin{array}{l}---- \\
44.13 \\
23.74 \\
0.051\end{array}$ & $\begin{array}{l}55.17 \\
55.37 \\
56.84 \\
0.035\end{array}$ & $\begin{array}{c}---- \\
11.6 \\
6.86 \\
0.050\end{array}$ & $\begin{array}{c}---- \\
83.41 \\
79.39 \\
0.041\end{array}$ \\
\hline
\end{tabular}

APU = Apparent Phosphorus Utilization

PHI $=$ Physiological Harvest Index

$\mathrm{AE}=$ Agronomic Efficiency

$\mathrm{PE}=$ Physiological Efficiency
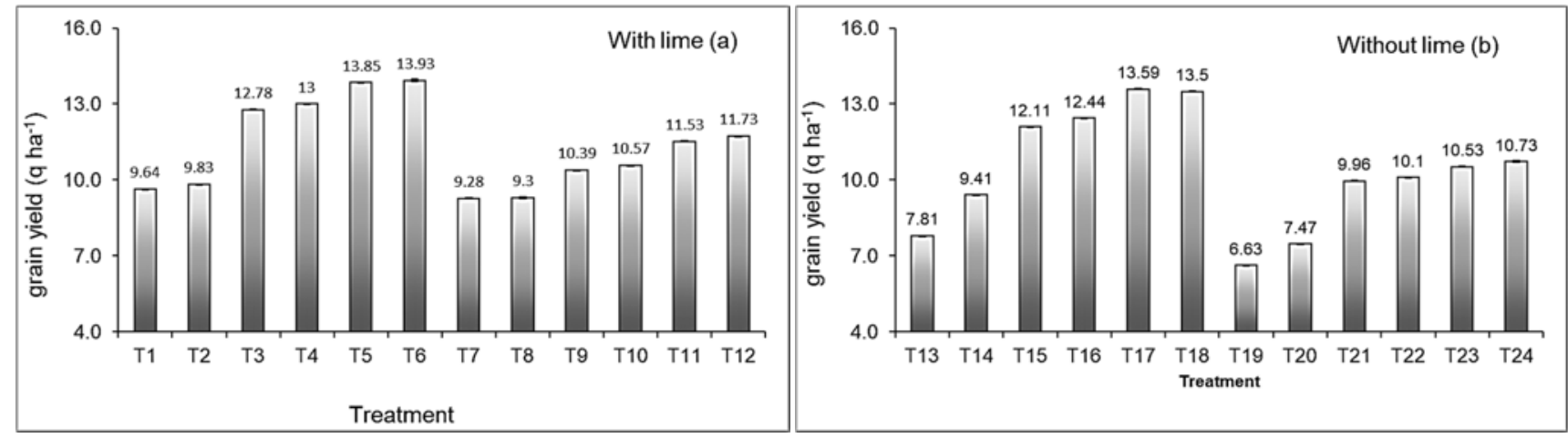

Fig 1: Combine effect of phosphorus, farm yard manure and boron on seed yield ( $q \mathrm{q}^{-1}$ ) of lentil under lime (a) and without lime (b) conditions of soil. Error bar indicates the standard deviation $(P<0.05)$

\section{Summary}

The present study was expected to give observation on phosphorus demand of the crop (lentil) under the Terai situation of West Bengal. The use efficiency of phosphorus at different treatment combinations was reflected towards the yield of the crop. The application of lime in acid soil in combination with B and FYM, significantly increased the yield of lentil under the Terai situation of West Bengal.

\section{References}

1. Baligar VC, Fageria NK, He ZL. Nutrient use efficiency in plants. Communication in Soil Science and Plant Analysis. 2001; 32:921-50.

2. Biswas PK, Bhowmick MK, Kundu MC, Mondal S, Ghosh GK. Conjoint application of biofertilizer and phosphorous levels on growth, nodulation, nutrient uptake and productivity of lentil [Lens culinaris 
Medikus] in red and lateritic soils of West Bengal. Journal Crop and Weed. 2015;11(1):29-32.

3. Bray RH, Kurtz LP. Determination of total, organic and available forms of phosphorus in soils. Soil Science. 1945; 59: 39-45.

4. Gomez KA, Gomez AA. Statistical procedure for agricultural research. J. Wiley and Sons, New York, 1984.

5. Graham ER. Availability of natural phosphates according to energy changes. Soil Science Society of America, Proceedings, 1995, 561-80.

6. Hussain M, Shah SH, Nazir MS. Differential genotypic response to phosphorus application in lentil (Lens culinaris Medic). International Journal of Agriculture and Biology. 2002; 4(1):61-3.

7. Jackson ML. Soil chemical analysis. Prentice-Hall of India Pvt. Ltd., New Delhi, 1973.

8. Johnson SE, Lauren JG, Welch RM, Duxbury JM. A comparison of the effect of micronutrient seed priming and soil fertilization on the mineral nutrition of chickpea (Cicer arietinum), lentil (Lens culinaris), rice (Oryza sativa) and wheat (Triticum aestivum) in Nepal. Experimental Agriculture. 2005; 41:427-48.

9. Kumar A, Brij Nandan R, Kumar J, Jamwal BS. Response of large seeded lentil to seed rate, phosphorus and FYM application in sub-tropical kandi-belt of Jammu and Kashmir. Journal of Food Legumes. 2010; 23(1):44-6.

10. Mahler RL, Shafii B. Relationship between soil-test boron and lentil yield in the Inland Pacific Northwest. Communications in Soil Science and Plant Analysis. 2007; 38(9):1193-02.

11. Mandal MK, Pati R, Mukhopadhyay D, Majumdar K. Maximization of lentil (Lens culinaris) yield through management of nutrients. Indian Journal of Agricultural Sciences 2009; 79(8):645-7.

12. Maqsood M, Hussain A, Khaliq A, Nawaz M. Effect of rhizobium inoculation and phosphorus on nodulation and yield of lentil (Lens Culinaris Medic). Pakistan Journal of Agricultural Science. 1994; 31(1):41-3.

13. Marschner H. In Mineral Nutrition of Higher plants, Second edition. Academic Press. Inc. London, G.B, 1995, 446p.

14. McLaughlin MJ, Alston AM, Martin JK. Transformation and movement of phosphorus of $\mathrm{P}$ in the rhizosphere. Plant Soil. 1987; 97:391-99.

15. Rathour DK, Gupta AK, Choudhary RR, Sadhu AC. Effect of integrated phosphorus management on growth, yield attributes and yield of summer green gram (Vigna radiata $\mathrm{L}$.). The Bioscan. 2015; 10(1):05-07.

16. Sharply AN. Phosphorus cycling in unfertilized and fertilized agricultural soils. Soil Science Society of America Journal. 1985; 49:905-11.

17. Singh DK, Singh AK, Singh SK, Singh M, Srivastava OP. Effect of balanced nutrition on yield and nutrient uptake of Pea (Pisum sativum L.) under Indo-Gangetic plains of India. The Bioscan. 2015; 10(3):1245-49.

18. Singh G, Wade LJ, Singh BB, Singh RK, Singh VP. Nutrient management in semi-deep water $(30-50 \mathrm{~cm})$ rice (Oryza sativa) and its effect on succeeding lentil (Lens culinaris) crop. Indian Journal of Agronomy. 2001; 46(1):12-6.

19. Singh SK, Varma SC, Singh RPd. Residual effect of organic and inorganic sources of nutrients in lowland rice on succeeding lentil. Indian Journal of Agricultural Research. 2004; 38(2):121-25.

20. Singha Roy AK, Maiti S, Bhattacharyya KK. Environment and Ecology. 1992; 10(4):837-41.

21. Togay Y, Togay N, Dogan Y. Research on the effect of phosphorus and molybdenum applications on the yield and yield parameters in lentil (Lens culinaris Medic.). African Journal of Biotechnology. 2008; 7(9):1256-60.

22. Wani MR, Dar AR, Tak A, Amin I, Shah NH, Rehman R et al. Chemo - induced pod and seed mutants in mungbean (Vigna Radiata L. Wilczek) SAARC J. Agri. 2017; 15(2):57-67.

23. Wen G, Chen C, Neill K, Wichman D, Jackson G. Is phosphorus fertilizer needed in winter pea and lentil production in central Montana. Fertilizer. 2006; 40:1. 